\title{
Faith, the postfoundational foundation of knowledge
}

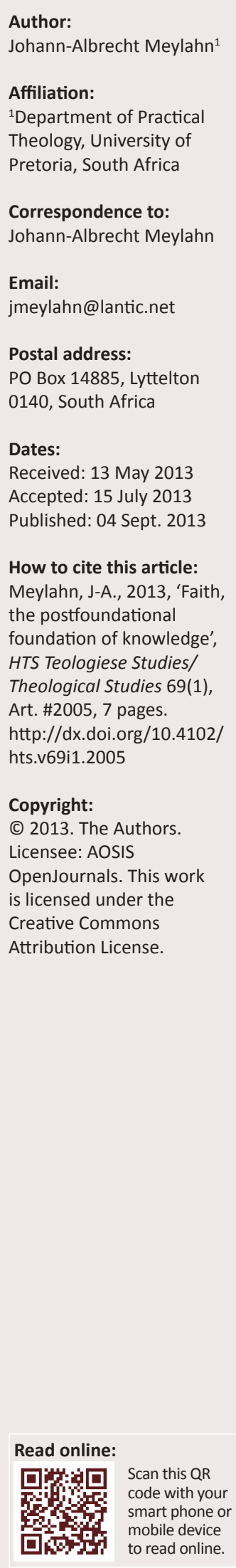

The article will focus on the role of faith in postfoundational epistemology and the extent to which our knowledge constructions are only possible in a context of faith. One inherits a language, a house of being, and this inherited language creates the world in which the various beings-of-one's-world find their place and have meaning. It is in this inherited world-ofmeaning that knowledge is constructed. Epistemology is therefore based on faith, believing in the linguistically socially created world, in the sense of believing in the world created by the silent speaking of language that creates the world-of-meaning in which one finds oneself. One unconsciously accepts this world created by language without taking into consideration the role of faith as one believes this created world to be the 'real' world. One takes for granted the world (worldview) into which one is born as the way things are. Life and knowledge are made possible by believing this world-of-meaning: language. In a global world where differing worlds-of-meaning come into contact with each other, faith can be disappointed and can lead to anger and violence. If one acknowledges the role of faith in one's epistemology, doors can be opened to multidisciplinary and multicultural dialogue as a multi-faith conversation.

\section{Introduction}

This article will focus on the role of faith in epistemology and the extent to which our knowledge constructions or epistemologies are founded on faith. Can one speak of faith and epistemology in the same sentence or are they supposed to be mutually exclusive? Faith is by definition something that is without evidence as it is based on blind faith. If one had evidence, it would not be faith but knowledge, and thus it seems that knowledge and faith are opposites. One either has knowledge or one has blind faith. Faith is related to credit. One can have very good reasons to believe somebody or something, and these reasons might even be counted as rational as they are based on the evidence of years of experience, as Russel Hardin (1992) has tried to argue. For faith to be faith and not 'sure' knowledge, the possibility of disappointed faith has to remain, which means that faith never comes with guarantees. Faith is something that is invested and where credit is given without absolute security. If there was absolute security, it would not be faith or credit but knowledge. The striving for secure knowledge characterised the modernistic understanding of knowledge, which in contrast to faith, is all about evidence and about what can be verified, tested and rationally justified.

This article will focus on the linguistic turn in epistemology and the dominant role that language plays in epistemology. Put differently, it is about the claim that epistemology is an event in and of language, a claim that therefore argues that epistemology is founded on faith. Taking this linguistic turn into consideration, faith is not just a given space, but it is foundational to epistemology. In this article, this foundational faith will be unpacked, beginning with the linguistic turn in epistemology by bringing Heidegger, Derrida and Agamben into conversation with each other.

\section{The linguistic turn}

The basic question of epistemology is: How does one know things? Why do things have meaning (make sense), and how do humans, as rational beings, discover this meaning? Epistemology, the study of knowledge, argues that beings, things or objects are known if they have meaning, that is, if they make sense. Things or beings have meaning (make sense) once they become accessible in their being. For example: How do I know a pen? The pen becomes meaningful as pen (it makes sense as pen) once its being as a writing tool is discovered and then one can say that one has knowledge of the pen. This epistemological process seems self-explanatory and makes absolute sense.

The basic unit of language is a sign which is made up of a signifier (sound-image or word) and a signified (sense). Thus what we have is the sense, namely writing tool (the signified), and the sound-image (signifier), namely pen. The meaning of the pen (its sense) is related to the naturally existing pen through the sound-image (the word pen), and all we actually have with which to make 
sense of the pen is the sound-image (signifier) that is related to its sense (signified), and this is the basic unit of language that allows one to find meaning. It is through language (signs) that we make sense of our world. The limits of our knowledge of the world are the limits of our language, as Wittgenstein argued that the limits of my language are the limits of my world (Wittgenstein 1974).

How does one know if language represents the world correctly?

The focus of epistemology can be interpreted as being concerned with the link between nature and thought, which is the link between the knower (subject) and known (object). What is this link between world and subject or between knowledge and objects? As Wittgenstein argued, the link is language. But how does one know whether something is true? What is the link between the naturally existing pen, on the one hand, and the sound-image (signifier: the word pen) and its sense (signified: a writing tool) on the other?

Something, namely a sign, has to be added to the naturally existing pen so as to have knowledge of the pen. To allow the naturally existing pen to stand out, to make sense as a writing tool, it has to be named. Thus the word or name has to be added to the naturally existing pen. This supplement to the naturally existing pen in turn has to be naturally or logically linked to the natural pen for there to be some surety that language is not betraying us. The link must be natural - either natural to the object itself or natural in the sense of being logically necessary, but it must not be artificial. An artificial link would be an interruption by something foreign, unnatural or irrational and thus needs to be avoided. Derrida, in his article '... That dangerous supplement ...' (Derrida 1997:141-164) unpacks the idea of the supplement that has to remain natural. Derrida does this by responding to Rousseau, who argues that the only way that the supplement can remain natural is in the voice (phonocentrism), which means that, according to Rousseau, writing would thus be an unnatural supplement. Derrida argues that writing is not a supplement to speech but that writing is all there is. Speech (sound-image or signifier: pen), which together with the signified (sense) is the basic unit of language (the sign), is already a supplement as the naturally vocalised word or name (pen) used to refer to something (signifier) is already a supplement of that something, and thus all there is are signifiers. The signifier (pen) refers to the sense (writing tool), but writing tool is also a signifier and not a signified and this continues ad infinitum. Signifiers point to other signifiers, never reaching a conclusive signified.

\section{Derrida (1997) interprets supplement in its dual meaning:}

1. It means that something is added. In Rousseau's case, writing is added to speech so as to make speech present in its absence (p. 144).

2. A supplement supplements in that it adds only to replace. 'It intervenes or insinuates itself in-the-place-of, if it fills, it is as if one fills a void' (p. 145).
Writing, as a supplement, does not only make speech present in its absence but also replaces speech (takes-the-place-of). The sign is the supplement of the thing itself. Rousseau warns that writing is dangerous as it is against both reason and nature (Derrida 1997:148). It is against nature as the sign is an artificial supplement and thus not natural, and it is against reason as reason wishes to deal with the natural 'real thing' rather than with the 'artificial' supplement. Thus for Rousseau, speech or the voice, which is natural, is primary, and writing is only the supplement. Derrida argues that speech is already a supplement and that one is always in the supplement as there is no outside of the text (Derrida 1997:158). Thus all there is is supplement. Reason is blind to this second signification of the supplement as reason believes that it is dealing with the natural 'thing itself'. Although being aware of Rousseau's warning, reason is justified in 'trusting' the sign as it believes that the sign is natural as there is some link between thought and object in speech, some link between signifier and signified. This logic is also found in Saussure's structuralism where he argues that, to protect the inner logic of language, a natural bond must be found between signifier (sound-image) and signified (sense). For Saussure, the only true bond is the bond of sound and thus of the voice, therefore giving priority to speech over writing (Derrida 1997:40). When reason introduces signs, it naturally believes that it is preserving presence beyond the presence of the present, and it does not think that this addition to the present is also the death of the present: the absence of the present. The use of the sign to represent presence is the absence of the present as it is represented and no longer present. The sign, language, represents nature and thus nature is absent. Or said differently, all there is a representation: The limits of my language (representation) are the limits of my world.

To ensure that the supplement is truthful, the unnatural supplement must be avoided at all costs. The inner logic of language, the natural logical link between signifier-signified, has to be protected at all costs (Derrida 1997:33-34). As I have argued:

Various theories and theologies have been created to protect this inner logic of language and thereby to protect the possibility of truth (truth as perfect imitation of presence or adequate representation of presence, thus truth thought on the basis of selfpresence. (Meylahn 2013:179)

To protect the inner logic from the poison of the pharmakon, ${ }^{1}$ the word and face of God must be invoked. ${ }^{2}$ Thus in the age of the sign, language will always be a kind of logocentrism [Word of God: logos] or phonocentrism where the voice is seen as natural and therefore primary. Agamben (2010), in his book The sacrament of language, develops a kind of theology or religion to protect the inner logic of language. The oath was introduced with the primary function of guaranteeing the truth and efficacy of language (Agamben 2010:4), that is,

1.See Derrida's discussion on the pharmakon, which is Plato's interpretation of writing as both remedy (that which preserves presence) but also poison (that which destroys presence) (Derrida 1981:99f.).

2.'The sign and divinity have the same place and time of birth. The age of the sign is essentially theological. Perhaps it will never end. Its historical closure is, however, outlined' (Derrida 1997:14). 
to guarantee the truth and efficacy of the sign and thus at all costs to prevent the poison of the supplement or pharmakon.

Traditionally, the oath evokes the name of God(s), and it does this twice: first as witness to what is said and second as curse for perjury. However, this is exactly the problem: The oath (in God's name) was introduced as a way to ensure truthfulness of language, but with the oath, the possibility of perjury is opened (Agamben 2010:6-7). Thus even the oath is no guarantee for the truthfulness and efficiency of language because with the oath is opened the possibility of perjury. It seems that there is no way to reach beyond this double possibility: oath - perjury, supplement - in-place-of, remedy - poison, as one is always in the text. Before I unpack that, however, I shall first turn to Agamben's argument.

Is the above the only way to understand the oath, namely as a way to ensure the truthfulness of what is said? To answer this, Agamben (2010) tries to understand what an oath is and why and how it is linked to the name of God(s).

Philo argues, in reference to the creation stories in Genesis, that divine speaking is unique in that God speaks, and what he has spoken is done. Thus, there is a direct connection between word and thing or word and reality (see Philo 1929:87ff.). The oath, which invokes God's name, is an attempt to conform human language to divine language where words and actions, words and reality, coincide. Thus the oath, speaking in God's name, is an attempt to make human language credible (pistos). Philo continues and argues that God is trustworthy, not because of the oath (Philo 1929:93), but because it is God who assures the oath. God's word, divine language, is an oath just as horkos [oath] is pistos par excellence in the classical tradition (Agamben 2010:22) and just as pistos (eman) [credit or trust] is the attribute of God par excellence: God is trustworthy as he is faithful, in the Judaic tradition. Philo thus establishes an essential connection between God and oath, making oath the very word of God: Logos is oath.

What is at stake in the oath is the relationship between words and things or language and reality. Agamben argues that the testimony is given by language itself, and the name of the ' $\operatorname{god}(\mathrm{s})$ ' is not a testimony of testimony but rather names a potential implicit in the very act of speech (Agamben 2010:33). The name of God is invoked in the oath, not as witness, but God's name explores the positive potential of language, which can be compared to the remedy of the pharmakon and the truthful relationship between words and things.

Usener, in his book Götternamen (1985), explores the use of divine names and the potential implicit in speech. The thesis of his book is that the names of the gods are initially names of actions or brief events (Usener 1985:75) and that these names were only later divinised in myth, art and poetry (Usener 1985:316). In other words, events and actions in the life of the community became identifiable as differentiated actions or differentiated events by the act of naming. These events and actions were named with divine names. The god (name) who presides over the singular activity or situation is nothing other than the very name of the activity or situation. What is divinised is the very event of the name, the nomination. Nomination which isolates (differentiates) and renders visible a gesture, an act, a thing, creates a 'special god' and is a 'momentary divinity' (Augenblicksgott). It is in naming that that which is named appears, and this is linked to a divine act of creation. The power of naming is divine power as names allow things to appear, as Agamben (2010) indicates:

Like the Sondergott, the god invoked in the oath is not properly the witness of the assertion or the imprecation: he represents, he is the very event of language in which words and things are indissolubly linked. (p. 46)

If in polytheism, the name assigned to the god names this or that event of language, this or that specific naming, this or that Sondergott, in monotheism God's name names language itself. (p. 49)

The potentially infinite dissemination of singular, divine events of naming gives way to the divinisation of the logos as such, to the name of God as archi-event of language that takes place in names (Agamben 2010:49). Language is the word of God, and the word of God is, in the words of Philo, an oath. It is God insofar as He reveals himself in the logos as the 'faithful one' (pistos) par excellence (Agamben 2010:49-50). God is the oath-taker in the language of which humanity is only the speaker. In the Cabbala, the metaphysical origin of all language is in the name of God (Scholem 1972:59ff.). Thus in monotheism, language becomes divine, that is, language becomes oath, it becomes LOGOS. To pronounce the name of God means to understand it as the experience of language in which it is impossible to separate name and being, words and things (Agamben 2010:52). That is to say, the name of God expresses the status of the logos in the dimension of fides, and thus in the oath, which is truthful, nomination immediately actualises the existence of what it names (Agamben 2010: 52-53). Every naming, every act of speech, is in this sense an oath in which the logos (the speaker in the logos) pledges to fulfil his or her word and swears on its truthfulness, on the correspondence between words and the things that is realised in it (Agamben 2010:46). The correspondence between words and things is realised in the logos.

The name of God names the name that is always true, that is, that experience of language that is not possible to doubt (Agamben 2010:54). If one pretends to formulate a veridiction as an assertion, an oath as a denotative expression, and (as the Church began to do from the 4 th century on by means of conciliar creeds) a profession of faith as dogma, then the experience of speech splits, and perjury and lie irreducibly spring up (Agamben 2010:58). It was in an attempt to check this split in the experience of language that law and religion were born. Both law and religion were born to seek to tie speech to things and to bind, 'by means of curses and anathemas, speaking subjects to the veritative power of their speech, to their "oath" and to their declaration of faith' (Agamben 2010:58). Something appears in that it is named (asserted), and in this original naming, assertion, it is true, and thus in the archi-event of language, the assertorial and verdictional aspects of language are inseparable (Agamben 2010:47). This is the archi-event of language to which Agamben seeks to return. 
Derrida's critique of Lacan (Derrida 1975) would probably also apply to Agamben's archi-event of language. Agamben's theory of the oath as the archi-event of language is a form of phonocentrism where there is correspondence between what is named and the thing named, and he would argue against logical necessity and/or the unity of assertorial and veridictional. Phonocentrism does not recognise the archiwriting (Derrida 1982, 1997) and that this oath or 'true word' (Lacan 1969), which is intended as a remedy (for the lack in nature), is already a supplement and thus an addition and an in-place-of and thus poison.

Reason is blind to think this double infringement of the supplement upon nature (Derrida 1997:149). The first infringement is that there is a lack in nature, and this lack is overcome by an addition: the supplement. Yet, as was discussed above, the supplement is never only an addition, but it is always also an in-place-of and thus the death (poison) of presence. Reason is powerless to think this, but it is not only powerless to think this. It is also constituted by this lack of power to think this (Derrida 1997:149). Meylahn (2013) points out:

Reason is founded on the idea that nature or presence can be supplemented by thought and that this addition of thought onto nature or presence or reality is natural. It does not think that this addition is also the death (poison) of nature, presence and/or reality in the sense that it is its absence. (p. 169)

Reason cannot think the supplement as its other, 'as the irrational and non-natural, for the supplement comes naturally to put itself in Nature's place' (Derrida 1997:149). This is the scandal of reason, and nothing seems more natural than this unthought-of deconstruction of Nature (Derrida 1997:151).

Derrida argues for archi-writing rather than archi-event of language as oath or God's word. This archi-writing is not oath but supplement and thus also always poison: the death of presence. God is indeed named in this archi-writing, not as the foundation of truth as oath but as the endless desertification of language (see Derrida 1995:55-56).

What reason (theories and theologies) does not think, or which is the very basis of reason and which therefore is not thought, is the unheard speaking of language (the 'upon which' the pen is thought), namely the archi-writing.

If one returns to the example of the pen: The pen (signifiersignified: word pen-writing tool) can only be revealed (unconcealed as such: writing tool) 'upon which' of a worldview where things (beings or objects) are viewed primarily on the basis ('upon which') of their usefulness as tools for humanity. This 'upon which' is not thought as it is concealed because the 'pen' that is to be thought appears, is unconcealed as a writing tool, and that it is a writing tool is as clear as daylight. What is not thought is that it appears as writing tool because it is part of this particular worldview or paradigm of thought. What is forgotten in this epistemology, or rather, what is not thought in this understanding of epistemology is that this being or thing or object that is understood is understood (has meaning) because it is projected 'upon which' it has meaning. It is this 'upon which' which first of all has meaning and makes understanding possible (Heidegger 1996:298). In other words, things, objects and beings have meaning (are comprehended) because they are thought 'upon which' of Being; they are thought within the metaphysical structures of the ontological difference between Being and beings. Things (beings), or in modern scientific terminology 'objects', can only be known or understood in their being if they are projected 'upon which' of Being. Thus our knowledge, epistemology and metaphysics are dependent on this world-of-meaning (worldview) 'upon which' beings appear to knowledge. Heidegger argues that what is not thought in these questions about truth, specifically in the Western tradition, is that assertions, which are either true or false, are - before they are true or false - linguistic (see Wisnewski 2008:131). This means that, before one can judge if statements are true or false, one needs to take note of the fact that they are statements made in language.

Take for example the statement: 'The dog is brown.' It is as clear as daylight that anyone who is in the vicinity of the dog that is referred to can judge this statement as either true or false by comparing the statement to the visible dog. What is not thought in this conception of truth is what makes the dog visible in the first place so that a true or false statement can be made concerning it (see Heidegger 1984:\$\$20-24). Before I can make an assertion that can be judged as either a true or false statement of something, that 'something' has to be visible and made manifest to me. This openness or visibility of entities has not been thought in the West. Truth in the West has been viewed as adequatio or correlatio and thus correctness, but this view of truth which seems selfgrounding (as clear as daylight) does not think the ground for this self-grounding: the concealed ground. Heidegger argues for a more foundational element of truth which is forgotten (Heidegger 1984).

What is to be thought or known is unconcealed, by speech (naming), but what remains concealed in the naming is that this naming takes place within a realm (worldview) or Gesichtskreis of which it is part. In other words, the worldview grants what is unconcealed its place and its sense, but this worldview, the Gesichtskreis, remains concealed. Heidegger (1984) takes both these elements of concealment and unconcealment into consideration in his concept of the truth of Being: aletheia, or as Caputo refers to it as on/aletheia (Caputo 1993:21-22). This truth of Being is dependent on the various epochal sendings of Being. The truth of things is dependent on the Gesichtskreis and/or on the paradigm in which it comes to view. For example, a river appears and is integrated into human knowledge or understanding. In a mytho-religious world (historical epoch of Being), it appears and is assimilated into knowledge as something divine as it is life-giving. Yet, this same river, in a different historical epoch of Being, would appear to knowledge as something that follows the various laws of nature. To both these historical epochs it would be as clear as daylight (on the basis of evidence) that this is what a river is. For the mytho-religious world, it is clear, based on evidence, that the river is a giver 
of life (both fish and water to fertilise the earth), and as giver of life, it must be divine. Modern scientists would strongly disagree with this mytho-religious view as they would argue that the river is a result of a combination of natural laws. What is not thought by both sets of researchers from both historical epochs is the role played by the 'upon which' or the Gesichtskreis (worldview) in which the river appears.

Heidegger tried to show or reveal this truth of Being (aletheia) as an Event of Being which is an Event of and in language. Language calls into and out of the dif-ference (Austrag) (Heidegger 1971:198-203). The dif-ference (Austrag) is the difference and co-dependence between Being (world) and beings (things) (see Heidegger 1969:65f; Caputo 1982:152). Language, exemplarily poetry, calls into the dif-ference and out of the dif-ference as beings gestate the world and/or Being, and world and/or Being grants beings their place in that gestated world (see Heidegger 1971:203-206; Meylahn 2013:72f.). This double stilling of beings gestating world and world granting beings a place is the silent speaking of language: the peal of stillness (Geläut der Stille) (Heidegger 1971:207). It is the silent speaking of language, in other words, it is that which is forgotten or not heard. Humans do not hear this silent speaking of language. One does not hear the Geläut der Stille. We cannot know that one is spoken by language, and therefore one cannot but think that the way the world appears (is created by language) is the way the world is. That which is perceived as natural, as an objective fact, like the pen before one, appears as pen as it is unconcealed within a certain world-of-meaning, but this unconcealing, which is simultaneously a concealing, is not thought. All that appears in the facticity of everyday Dasein is the object which is taken to be an objective reality: a fact - it is a pen! What does not appear and remains concealed with the appearance of the object is the unconcealing of the object, the 'upon which' of a particular world-of-meaning. Humans respond to this appearing of objects with mortal speech unaware that this appearing is already the silent speaking of language.

This world-of-meaning, the 'upon which' beings become meaningful, is created (gestated) by the very beings or things, but likewise, this world-of-meaning (Gesichtskreis) grants these things their place in this world-of-meaning. It is this co-dependence and yet difference between things and world or beings and Being that makes it so difficult to take note of it, and thus it is forgotten or not thought. It is not as if one can experiment and take the pen out of its world-ofmeaning and place it in another world-of-meaning because the pen and its world-of-meaning are dependent on each other. It is the pen, together with other things (tools), that gestates (gives birth to) the world-of-meaning, and in turn, it is this world-of-meaning that grants the pen its place in this world as a writing tool. The two cannot be separated, and thus it is not thought.

One inherits a language, a house of being (Heidegger 1971: 192), and this inherited language creates (poiesis) a world. Epistemology is dependent on this speaking of language (Geläut der Stille). This created (poiesis) world-of-meaning appears as natural to the self as the air one breathes and therefore one is not conscious thereof and thus forgets the role of Being, or rather the truth of Being as an Event of Being (the silent speaking of language) (Heidegger 1984). Forgetting Being (Seinsvergessenheit), one presumes that this is the way the world is, forgetting the silent speaking of language (the Event of Being) and the role of language in epistemology knowledge of things and the world (Heidegger 1971). One tends to forget the foundational speaking of language before one responds to the created (poiesis) world with her things in mortal language.

Humans believe themselves to be 'using' language as a tool with which to comprehend the world without realising that they are already spoken for in the speaking of language, and there is no escape as one is always in language, or as Derrida argues, there is nothing outside the text (Derrida 1997:158). The self is part of this Dasein of a given world as the self is implicated in the Gesichtskreis, and thus the self (knower or researcher) is already implicated in the world that the self is trying to get to know. The self is already spoken before responding in mortal speech by the silent speaking of language. The self becomes a conscious self in that the self is assimilated into this world-of-meaning and finds a place therein. This world-of-meaning can be the social-culturallinguistic community of which one is part, or it could also be the specific scientific paradigm in which one was trained and from which one does research. It is through this paradigm or world-of-meaning that one views the world (worldview) and comprehends the things of the world. This view is taken for granted as being true and therefore it taken for granted. In the case of social-cultural language, it is what is believed to be natural. In the case of scientific paradigms, there are sufficient reasons (evidence) to declare the paradigm to be true.

It is in this circularity that faith will be investigated. One takes for granted as the real world the worldview into which one was born and which one has inherited from the socialcultural context without considering that it is a world given to view, and that it is an event of language and that one is spoken even before one speaks. One believes one's worldview to be the way the world truly is. This belief is as 'natural' and thus unquestionable as the air that one breathes. The world is taken to be true, with sufficient evidence, and therefore the question of truth does not even come to mind as this view is taken to be natural (objective), it is the way the world is.

Heidegger, in his linguistic turn, revealed the forgotten role of language in all human rationality and epistemology and that humans are spoken by language even before they respond in mortal speech to the world which they believe appears 'naturally' to them and that they seek to understand, comprehend and know. In other words, there is no bird's eye view of this relationship between language and nature as one who seeks this bird's eye view is always already in language (in the text). There is an archi-writing or the silent speaking of language (Heidegger) that is not thought and from which one cannot escape, one cannot get outside of it. 
This speaking of language, Derrida further unpacks with his idea of différance $e^{3}$ or archi-text. As mentioned above, it is not an archi-event of language, but one is always already in the text (in the speaking of language) and thus an architext. This speaking of language (différance) opens up a ZeitSpiel-Raum - which is the dwelling of being - the dwelling of humanity. This archi-writing (the speaking of language) is an effect of dif-ference, as Heidegger had already shown, or an effect of Derrida's différance. Heidegger's dif-ference (Austrag) is the silent calling of language into and out of the dif-ference. Differrance is the becoming-space of time and the becoming-time of space (Derrida 1982:8) of the speaking of language as an effect of the difference and deferment inherent in language (see Derrida 1982:7, n. 7). Différance creates (poeisis) the time-space (Zeit-Spiel-Raum) ${ }^{4}$ which is the dwelling of being or the habitat for humanity. Différance effects the timespace for humanity or the context in which humans dwell. Thus one can say that language creates the context for human life and history. Although différance does not create anything, language (différance) creates the becoming-time of space and the becoming-space of time, and this becoming of time-space is characterised by an endless play of difference and deferment and thus a Zeit-Spiel-Raum (see Derrida 1978:36-76).

Yet this play of difference and deferment, this play of différance, is not arbitrary, but borrowing the idea from Levinas, Derrida argues for an instituted trace (Derrida 1982:12, 21, 1997:46). The idea of the trace is a faint memory of a past never present and a future always still to come (Derrida 1982:12, 21). The trace helps one to think the beyond activepassive nature of différance's opening of a Zeit-Spiel-Raum in which meaning and the deconstruction of meaning become possible. Both meaning and the deconstruction of meaning, by opening meaning for what was but was never present and what is always still to come, is made possible in this ZeitSpiel-Raum. The Zeit-Spiel-Raum is a space opened up by language for the dwelling and history of humans. Language entrusts humanity to Zeit-Spiel-Raum, or put differently, différance opens a space - the becoming-time of space and the becoming-space of time - for humanity and human history.

Agamben, like Derrida and Heidegger, argues that language hallows out a space for human dwelling. Derrida's différance opens a Zeit-Spiel-Raum, and Agamben's oath hallows out a space and opens a Zeit-Raum for human dwelling ${ }^{5}-$ a

3.Derrida unpacks Heidegger's silent speaking of language by translating and interpreting dif-ference with his neologism: différance (see Bennington 1993:272).

4.'Différance opens (not actively nor passively) the time-space or what Caputo referring to Heidegger might refer to as the Zeit-Spiel-Raum' (Caputo 1993:30). 'Zeit-SpielRaum that capture something of the time-space, but also the play in that time-space between meaning and non-meaning, absence and presence, etcetera' (Meylahn 2013:201).

5.'The decisive element that confers on human language its peculiar virtue is not in the tool itself but in the place it leaves to the speaker, in the fact that it prepare within itself a hollowed-out form that the speaker must always assume in order to speak - that is to say, in the ethical relation that is established between the speake and his language' (Agamben 2010:71). The lack that is experienced in nature is and hupplemented with a not supplemented with a sign, but humans have placed themselves in that gap as humans have put their very nature at stake in language (Agamben 2010:68). Just as Foucault said that man is an animal whose politics places his existence as a livin being in question (Foucault 1990:143), so it can also be said of language, namely that humanity is a living being whose language places her life in question (Agamben 2010:69). These two need to be thought together as they are inseparable and constitutively dependent on each other. hallowed out space for humanity, This space is an ethical space that binds the subject to language: the sacrament of language. ${ }^{6}$ It is also in this space of the archi-event of language that the ethical, political and actions are connected.

What is the ethical relationship between the speaker and language? For Agamben, the ethics that binds (religare) the subject to the polis is the oath. ${ }^{7}$ In the political (polis), there is a plea for a return of ethics - the ethics of the oath. It is an ethics that binds (religare) one to a specific symbolic order and the truthfulness of language, and this ethics has the power to counter the challenge of our time (worldview), namely blasphemy: blasphemy as the vanity of language, the emptiness of language, but also the blasphemy of the misuse of God's name in vain with all the various forms of dogmatism and fundamentalism both in religion and science. Thus Agamben calls for a return of the oath and the sacrament of language where one is bound by an ethics of the oath to the language. This is a call to the return of truthful speech that is modelled on the logos of God. It is a call to the return of the oath as it is the oath that binds together the democracy (Lycurgus 1962:79). It is a call for the return of truthful and trustworthy language.

What is the difference between Agamben's space hallowed out by language for the speaking human and the Zeit-SpielRaum? The difference is the Spiel in the Zeit-Spiel-Raum. The Spiel is left out in the oath that binds people into the polis, but it forgets that this time-space is a supplement (the archiwriting of the speaking of language of a particular epoch), thus reintroducing the play of différance and opening this time-space for the trace: a past never present and a future always still to come.

This archi-writing and the play of the trace, Derrida calls the name of God: the endless desertification of language - the endless play of language where all there is is a trace: a past never present and a future always still to come.

There is a call for a return of God. This call is not for the God of logos according to Agamben with an ethics of the oath but for the God as the endless desertification of language with only a trace. Thus opening the time-space for what is always still to come.

In God we trust - that is all we have. However, this is not a fixed oath, logos, but a play and an opening of the democracy (polis bound by the oath: God) for what is still to come: democracy still to come, knowledge still to come, research still to come. In God (endless desertification of language) we trust, which is the official motto of the USA, is an ideal motto as the foundation for a secular democracy: the living space

6.... the oath is a consecration of the living human being through the word to the word' (Agamben 2010:66).

7.The oath is situated at the intersection of humanity as political animal and humanity as linguistic animal. The inth is the anthropogenic operator 'by means of which the living being, who has discovered itself speaking, has decided to be responsible for his words and devoting himself to the logos, to constitute himself as the living being who has language' (Agamben 2010:69). Thus the oath binds together in an ethical and political connection words, things and actions (Agamben 2010:69). 
polis for life together. In God we trust is the oath that ethically binds humans to language and thus binds (religare) humans into a polis (Zeit-Spiel-Raum), a living space for life together, but a space that is created by différance - the speaking of language of a particular epoch - and therefore remains open for the other, other epochs as well as the epochs still to come. Thus it is faith pure without any security in what is still to come: a messianic faith in the other to come without a concrete messiah (interpretation of the other).

\section{Conclusion}

Societies and cultures or scientific communities believe that their worldview is correct, that it is as the world truly is. This belief if based on an arbitrary metaphysical idea, an ultimate reference, which binds their world together, that is, allows the different things of that world to find a place therein. It is a belief in the Sondergötter that binds language or culture to reality. Yet, in a global world, one comes into contact with numerous other worldviews, and thus, one's worldview is questioned. This questioning can either result in violence between the different worldviews competing with each other or, if the role of faith is acknowledged in all worldviews and/ or epistemologies, a space for conversation can be opened. Derrida differs from Agamben concerning his take on the relationship between God and language. As argued above, his idea of différance introduces the possibility of play.

If the role of faith or religion (religare) is acknowledged in all epistemologies and worldviews, this could open a space, a democratic space, for multi-faith and multidisciplinary conversations where other voices are welcomed. It would be a democratic space where no voice dominates or is foundational but a postfoundational space where the various foundations are recognised and appreciated, without any of them taking a dominant or foundational position. This conversation would be open to the future, realising that there will always still be another other voice to welcome. It will be a democratic space under the motto, in God we trust, where faith is placed in God as the infinite desertification of language or the openness and playfulness of language, beyond singular foundations, thus binding (religare) the democratic space to continuous postfoundational conversations.

\section{Acknowledgements Competing interests}

The author declares that he has no financial or personal relationship(s) that may have inappropriately influenced him in writing this article.

\section{References}

Agamben, G., 2010, The sacrament of language: An archaeology of the Oath (Homo Sacer II,3), transl. A. Kotsko, Polity Press, Cambridge.

Bennington, G., 1993, 'Derridabase', in G. Bennington \& J. Derrida, Jacques Derrida transl. G. Bennington, University of Chicago, Chicago.

Caputo, J.D., 1982, Heidegger and Aquinas: An essay on overcoming metaphysics, Fordham University Press, New York. PMCid:PMC256754

Caputo, J.D., 1993, Demythologizing Heidegger, Indiana University Press, Indianapolis.

Derrida, J., 1975, 'The purveyor of truth', transl. W. Domingo, J. Hulbert, M. Ron, Yale French Studies, 52 (Graphesis: Perspectives in Literature and Philosophy), 31-113 Derrida, J., 1978, Writing and difference, transl. A. Bass, Routledge, London.

Derrida, J., 1981, Dissemination, transl. B. Johnson, Continuum, New York. PMid:6910236 Derrida, J., 1982, Margins of philosophy, transl. A. Bass, Harvester, Brighton.

Derrida, J., 1995, 'Sauf le nom' in J. Derrida \& T. Dutoit (eds.), On the name, transl. D. Wood, J.J. Leavey \& I. McLeod, pp. 35-88, Stanford University Press, Stanford.

Derrida, J., 1997, Of grammatology, transl. G.C. Spivak, John Hopkins Press, Baltimore

Foucault, M., 1990, History of sexuality, vol. 1: An introduction, transl. R. Hurley, Vintage, New York.

Hardin, R., 1992, 'The street-level epistemology of trust', Analyzse \& Kritik 14, 152-176.

Heidegger, M., 1969, Indentity and difference, transl. J. Stambaugh, Harper \& Row, New York.

Heidegger, M., 1971, Poetry, language and thought, transl. A. Hofstadter, Harper \& Row, New York.

Heidegger, M., 1984, Grundfragen der Philosophie: Ausgewählte 'Probleme' der Logik, Gesamtausgabe, B. 45, Klostermann, Frankfurt.

Heidegger, M., 1996, Being and time: A translation of Sein und Zeit, transl. J. Stambaugh, State University of New York, New York.

Lacan, J., 1969, The language of the self: The function of language in psychoanalysis, transl. \& ed. A. Wilden, Baltimore, John Hopkins.

Lycurgus, 1962, 'Against Leocrates', in J.O. Burtt (ed.), Minor Attic orators, transl. J.O. Burtt, vol. 2, pp. 14-133, Harvard University Press, Cambridge.

Meylahn, J.A., 2013, The limits and possibilities of postmetaphysical God-talk: A conversation between Heidegger, Levinas and Derrida, Peeters Publishers, Leuven. (Studies in Philosophical Theology, 52).

Philo of Alexandria, 1929, 'On the birth of Abel and the sacrifices offered by him and his brother Cain (De sacrificiis Abeis et Caini)', in Philo, transl. F.H. Colson \& G.H. Whitake, vol. 2, pp. 87-195, Putnam, New York.

Scholem, G., 1972, 'Judaica, That Name of God and the Linguistic Theory of the Kabbala', transl. S. Pleasance, Diognes 20, 79-80, 59-194.

Usener, H., 1985, Götternamen: Versuch einer Lehre der religiösen Begriffsbildung, Klosterman, Frankfurt am Main.

Wisnewski, J.J., 2008, 'The case of anti-antirealism: Wittgenstein, Heidegger, and Aristotle on language and essence', Philosophical Frontiers 3(2), 125-141.

Wittgenstein, L., 1974, Tractatus Logico-Philosophicus, Routledge, London. 